Vol.5, No.1, April 2021, hlm. 164-182 DOI: $10.37274 /$ rais.v5i1.395

\title{
Tinjauan Fatwa DSN MUI Terhadap Penyelesaian Pembiayaan Murābahah Bermasalah (Studi Kasus di Bank Pembiayaan Rakyat Syariah Dana Amanah Surakarta)
}

\author{
Mujahidin Yunani, M. Usman \\ IAIN Surakarta, Indonesia \\ Mujahidinyunani80@gmail.com, Usmanmadura68@yahoo.co.id
}

\begin{abstract}
Murābahah is one of the most popular financing for Sharia Financial Institutions. Likewise, at the BPRS Dana Amanah Surakarta, murābahah financing is what customers are most interested in, therefore, among other financing products the risk is also higher. In addition, many customers choose deferred payments. This deferred payment creates several risks, one of which is financing problems. Many customers who are deemed capable are still procrastinating in terms of payment of installment obligations, this is what causes losses for the BPRS, where the more customers delay payment, the higher the level of Non Performing Financing (NPF) in a bank, causing the bank's condition to not healthy. Then the problem that will be raised in this study is how to solve the problematic murābahah financing in the BPRS Dana Amanah Surakarta and how the view of the fatwa DSN MUI towards the practice of solving the problematic muräbahah financing in the BPRS Dana Amanah Surakarta. This study uses field research methods, with a descriptive qualitative approach. The data sources used are primary data and secondary data, with data collection methods through interviews with informants and documentation and then analyzed with qualitative descriptive methods. From the results of this study, it can be concluded that: (1) The steps for solving problematic murābahah financing at BPRS Dana Amanah Surakarta include billing, rescheduling, restructuring, customers selling their own goods, execution of collateral, AYDA and judicial channels. (2) The mechanism for the settlement of murābahah financing at BPRS Dana Amanah Surakarta is in accordance with the MUI DSN Fatwa and POJK No. 29/POJK.03/2019, except for the Fatwa DSN MUI No. 47 / DSN-MUI / II / 2005 on the provisions of point 5 regarding exemption for customers who are truly unable to pay off their financing payments, because in its implementation the BPRS Dana Amanah Surakarta implementing the final solution of problematic murābahah financing by way of settlement through the judiciary, if the BPRS performs debt relief, only the write-off records are written off, not the write-offs. Even though it has been written off, there is still a billing.
\end{abstract}

Keywords : Financing, Murābaḥah, Non Performing Financing, Fatwa DSN MUI.

\section{Pendahuluan}


Lembaga perbankan di Indonesia sendiri terbagi menjadi 2 (dua) yakni bank konvensional dan bank syariah, sebagaimana yang telah dijelaskan dalam Pasal 1 Undang-Undang (UU) Nomor (No) 21 Tahun 2008 tentang Perbankan Syariah: Bank konvensional adalah bank yang menjalankan kegiatan usahanya secara konvensional dan berdasarkan jenisnya terdiri dari bank umum dan bank perkreditan rakyat. Sedangkan bank syariah adalah bank yang menjalankan kegiatan usahanya berdasarkan prinsip syariah dan menurut jenisnya terdiri dari bank umum dan bank pembiayaan rakyat syariah. ${ }^{1}$

Bank Pembiayaan Rakyat Syariah (BPRS), yang membedakannya dengan bank syariah. Dalam UU No. 21 Tahun 2008, adalah dalam kegiatannya tidak memberikan jasa dalam lalu lintas pembayaran. Dalam ketentuan UU No. 10 Tahun 1998, untuk bank syariah tidak digunakan istilah "perkreditan" melainkan "pembiayaan". ${ }^{2}$

Dalam penjelasan Pasal 8 UU No. 21 Tahun 2008 tentang Perbankan Syariah antara lain dinyatakan bahwa kredit atau pembiayaan berdasarkan prinsip syariah yang diberikan oleh bank mengandung resiko, sehingga dalam pelaksanaannya bank harus memperhatikan asas-asas atau pembiayaan berdasarkan prinsip syariah yang sehat. Berbagai resiko yang harus ditanggung oleh bank antara lain berupa :

1. Utang/ kewajiban pokok pembiayaan yang tidak dibayar

2. Margin/bagi hasil/fee tidak dibayar

3. Membengkaknya biaya yang dikeluarkan ${ }^{3}$

Pembiayaan murābahah merupakan pembiayaan dengan peminat tertinggi di

BPRS Dana Amanah Surakarta dapat dilihat dari tabel di bawah ini :

Tabel 1.1

Fasilitas Pembiayaan yang Disalurkan BPRS Dana Amanah Surakarta Tahun 2017-2020

\begin{tabular}{|c|c|c|c|c|c|c|c|c|}
\hline \multirow[b]{2}{*}{ Tahun } & \multirow[b]{2}{*}{ Bulan } & \multicolumn{7}{|c|}{ Pembiayaan } \\
\hline & & Murābahah & Istīshhnā' & $\begin{array}{c}\text { Ijārah } \\
\text { Multijasa }\end{array}$ & Qardh & Ijārah & Mudhārabah & Musyārakah \\
\hline 2017 & $\begin{array}{l}\text { Mar, Jun, } \\
\text { Sep, Des }\end{array}$ & $53,964,030$ & 88,183 & $23,331,542$ & 0 & 0 & $1,500,922$ & 448,891 \\
\hline 2018 & $\begin{array}{l}\text { Mar, Jun, } \\
\text { Sep, Des }\end{array}$ & $56,137,213$ & 54,464 & $22,491,919$ & 0 & 0 & 487,064 & $3,379,107$ \\
\hline 2019 & $\begin{array}{l}\text { Mar, Jun, } \\
\text { Sep, Des }\end{array}$ & $75,020,732$ & 179,461 & $40,368,579$ & 33,000 & 0 & 795,653 & $11,659,044$ \\
\hline 2020 & Mar & $17,717,216$ & 59,090 & $10,521,593$ & 0 & 0 & 192,075 & $4,089,612$ \\
\hline
\end{tabular}

Sumber : Data Olahan Laporan Publikasi KAP dan Informasi Lain Otoritas Jasa Keuangan https://www.ojk.go.id/.

1 Undang-Undang Nomor 21 Tahun 2008 tentang Perbankan Syariah (Lembar Negara Republik Indonesia Tahun 2008 Nomor 94, Tambahan Lembaran Negara Republik Indonesia Nomor 4867).

${ }^{2}$ Gemala Dewi, dkk, Hukum Perikatan Islam di Indonesia (Jakarta: Kencana, 2005), hlm. 166-167.

${ }^{3}$ Faturrahman Djamil, Penyelesaian Pembiayaan Bermasalah di Bank Syariah (Jakarta: Sinar Grafika, 2014), hlm. 64. 
Dari tabel di atas dapat dilihat bahwa penyaluran pembiayaan terbesar yakni pembiayaan murābahah, disusul dengan ijārah multijasa, musyārakah, mudḥārabah, istīshnnā', qardḥ dan ijārah. Maka dari itu pembiayaan murābaḥah memiliki resiko pembiayaan bermasalah lebih tinggi ketimbang dengan pembiayaan lainnya.

Rasio pembiayaan bermasalah atau Non Performing Financing (NPF) merupakan rasio yang yang digunakan untuk mengukur pembiayaan bermasalah suatu bank. NPF pada perbankan syariah juga merupakan salah satu dari sekian banyak indikator untuk melihat sebuah kinerja perbankan. ${ }^{4}$ Berikut sebagai data awal yang dapat dikemukakan terhadap tingkat NPF PT. BPRS Dana Amanah Surakarta, dari tahun 2017-2020 :

Table 1.2

Tingkat Non Performing Financing (NPFnett)

Triwulan Tahun 2017-2020 di BPRS Dana Amanah Surakarta

\begin{tabular}{|c|c|c|c|c|}
\hline Bulan/Tahun & 2017 & 2018 & 2019 & 2020 \\
\hline Maret & $7,76 \%$ & $21,27 \%$ & $12,89 \%$ & $17,92 \%$ \\
\hline Juni & $7,15 \%$ & $13,03 \%$ & $11,70 \%$ & $\mathrm{X}$ \\
\hline September & $11,90 \%$ & $11,01 \%$ & $14,37 \%$ & $\mathrm{X}$ \\
\hline Desember & $9,87 \%$ & $11,30 \%$ & $10,95 \%$ & $\mathrm{X}$ \\
\hline
\end{tabular}

Sumber : www.OJK.go.id

Berdasarkan tabel data NPF di atas, terlihat bahwa presentase nilai NPF di BPRS Dana Amanah Surakarta mengalami kenaikan setiap tahunnya yang di mana rata-rata NPF di atas 5\%, NPF yang baik adalah NPF yang memiliki rasio di bawah $5 \%$ karena semakin kecil nilai NPF maka semakin kecil pula resiko pembiayaan yang ditanggung bank dan semakin sehat pula kualitas aktiva bank tersebut. ${ }^{5}$ Dari data di atas dapat kita ketahui bahwasanya lonjakan pembiayaan bermasalah masih menghantui BPRS Dana Amanah Surakarta.

Berikut data yang dapat dikemukakan terhadap jumlah pembiayaan murābaḥah bermasalah di BPRS Dana Amanah Surakarta dari tahun 2017-2020 :

\section{Tabel 1.3}

Jumlah Pembiayaan Murābahah bermasalah di BPRS Dana Amanah Surakarta

Tahun 2017-2020

\begin{tabular}{|c|c|c|c|}
\hline \multirow{2}{*}{ Tahun } & \multirow{2}{*}{ Bulan } & Jumlah Pembiayaan & Pembiayaan Bermasalah \\
\cline { 3 - 4 } & & (ribuan Rp) & (ribuan Rp) \\
\hline 2017 & Mar, Jun, Sep, Des & $53,964,030$ & $3,526,379$ \\
\hline 2018 & Mar, Jun, Sep, Des & $56,137,213$ & $4,442,255$ \\
\hline
\end{tabular}

\footnotetext{
${ }^{4}$ Rindang Nuri Isnaini dan Syafrildha Bimo,”Analisis Faktor Internal...

${ }^{5}$ Ibid., hlm. 43.
} 
Tinjauan Fatwa DSN MUI Terhadap Penyelesaian Pembiayaan Murābaḥah Bermasalah (Studi Kasus di Bank Pembiayaan Rakyat Syariah Dana Amanah Surakarta)

\begin{tabular}{|c|c|r|r|}
2019 & Mar, Jun, Sep, Des & $75,020,732$ & $8,562,782$ \\
\hline 2020 & Mar & $17,717,216$ & $3,431,221$ \\
\hline
\end{tabular}

Sumber: Data olahan Laporan Publikasi KAP dan Informasi Lain Otoritas Jasa Keuangan https://www.ojk.go.id/

Dalam penyelesaian pembiayaan murābaḥah bermasalah pada perbankan syariah sudah diatur dalam peraturan otoritas jasa keuangan (POJK) dan fatwa dewan syariah nasional (DSN) majelis ulama Indonesia (MUI) dengan begitu baik POJK dan Fatwa DSN MUI dapat dijadikan sebagai rujukan dan pedoman dalam mengatasi pembiayaan murābaḥah bermasalah. Sebagai contoh dalam Fatwa DSN MUI No. 47/DSN-MUI/II/2005 tentang penyelesaian piutang murābaḥah bagi nasabah yang tidak mampu membayar, poin 5 (lima) menjelaskan apabila nasabah tidak mampu membayar sisa utangnya, maka lembaga keuangan syariah (LKS) dapat membebaskannya. ${ }^{6}$

Namun pada realitas lapangan apabila nasabah tidak mampu membayar hutangnya melebihi jangka waktu yang disepakati, tidak semua LKS mampu membebaskan utang nasabahnya, banyak LKS memilih langkah penyelamatan merestrukturisasi ketimbang pembebasan utang, karena upaya write-off akan membuat LKS perlu meningkatkan pencadangan dan menggerus modal dan laba LKS, dan hanya beberapa LKS yang memiliki rasio kecukupan modal di sekitar ambang batas minimum yang melakukan upaya ini.

\section{Pembiayaan Murābaḥah}

Pembiayaan murābaḥah adalah perjanjian pembiayaan dengan sistem jual beli, yakni bank yang akan membelikan barang sebagaimana pesanan nasabah, kemudian harga barang dilebihkan sebagaimana keuntungan jual beli bagi bank bersangkutan. Nasabah yang membutuhkan berbagai barang akan dilayani dengan sistem jual beli penangguhan. Nasabah akan membayar harga pembelian barang atau asset tersebut ditambah mark up/profit yang disepakati dan dibayar secara angsur sesuai dengan jangka waktu yang disepakati. ${ }^{7}$

\section{Wanprestasi}

Wanprestasi, artinya tidak memenuhi kewajiban sebagaimana ditetapkan dalam perikatan atau perjanjian. Tidak dipenuhinya kewajiban dalam suatu perjanjian, dapat disebabkan dua hal, yaitu: ${ }^{8}$

a. Karena kesalahan debitur baik sengaja maupun karena kelalaian

${ }^{6}$ Fatwa DSN MUI No. 47/DSN-MUI/II/2005 tentang Penyelesaian Piutang Murābaḥah Bagi Nasabah yang Tidak Mampu Membayar.

${ }^{7}$ Muhammad Asro dan Muhammad Kholid, Fiqh Perbankan (Bandung: CV. Pustaka Setia, 2011), hlm. 132.

${ }^{8}$ Djaja S. Meliala, Perkembangan Hukum Perdata ..., hlm. 99. 
b. Karena keadaan memaksa (overmacht).

Terdapat 4 keadaan wanprestasi, yaitu:

a. Tidak memenuhi prestasi

b. Terlambat memenuhi prestasi

c. Memenuhi prestasi secara tidak baik

d. Melakukan sesuatu yang menurut perjanjian tidak boleh dilakukannya.

Dalam hal wanprestasi karena kesalahan debitur baik sengaja maupun karena kelalaian, seorang debitur dianggap telah melakukan wanprestasi jika dalam suatu perjanjian tenggang waktu melaksanakan prestasi ditentukan, maka debitur berada dalam keadaan wanprestasi setelah lewat tenggang waktu yang ditentukan. Seperti seorang debitur yang telat membayar cicilan motor/ tidak membayar kelanjutan cicilan terhadap kreditur maka si debitur dinyatakan melakukan wanprestasi. Walaupun demikian menurut Pasal 1238 KUHPer, masih memerlukan teguran dari pengadilan (somasi) baru dapat dikatakan debitur dalam keadaan wanprestasi. ${ }^{9}$

Bagaimana dalam hal jika tenggang waktu tidak ditentukan dalam hal ini debitur perlu diperingatkan/ditegur terlebih dahulu. Tegurannya berupa:

a. Secara tertulis pribadi, disebut dengan istilah in-gebreke stelling;

b. Secara tertulis melalui pengadilan (somasi).

Teguran secara tertulis melalui pengadilan ini sebagaimana dinyatakan dalam Pasal 1238 KUHPer sudah tidak berlaku lagi, karena ketentuan ini telah dicabut dan dinyatakan tidak berlaku oleh surat edaran Mahkamah Agung (MA) No. 3/1963. Oleh karena itu menurut Subekti, cukup ditegur saja secara pribadi baik lisan maupun tertulis.

Akibat Hukum Wanprestasi

a. Debitur diharuskan membayar ganti rugi (Pasal 1243 KUHPer);

b. Kreditur dapat minta pembatalan perjanjian melalui pengadilan (Pasal 1266 KUHPer);

c. Kreditur dapat minta pemenuhan perjanjian, atau pemenuhun perjanjian disertai ganti rugi dan pembatalan perjanjian disertai dengan ganti rugi (Pasal 1267 KUHPer). ${ }^{10}$

\section{Force Majeur}

Keadan-keadaan yang terjadi di luar kekuasaan nasabah yang berdampak secara langsung dan materiil sehingga nasabah tidak dapat memenuhi kewajibannya seperti gempa bumi, badai, angin topan, banjir, kebakaran, tanah longsor,

\footnotetext{
${ }^{9}$ Ibid.

${ }^{10}$ Ibid., hlm. 100-101.
} 
peperangan, embargo, pemogokan umum, hura-hura, peledakan dan pemberontakan. ${ }^{11}$

\section{Pembiayaan Bermasalah}

Dalam statistik perbankan syariah uang diterbitkan oleh direktorat Perbankan Syariah Bank Indonesia dapat dijumpai istilah Non Performing Financing (NPF) yang diartikan sebagai pembiayaan tidak lancar, yakni pembiayaan yang kualitasnya berada dalam golongan kurang lancar, diragukan dan macet. ${ }^{12}$

Pembiayaan bermasalah tersebut dari segi produktivitasnya yaitu dalam kaitannya dengan kemampuannya menghasilkan pendapatan bagi bank, sudah berkurang/menurun dan bahkan sudah tidak ada lagi. Bahkan dari segi bank, sudah tentu mengurangi pendapatan, memperbesar biaya pencadangan, yaitu penyisihan penghapusan aktiva produktif (PPAP), sedangkan dari segi nasional, mengurangi kontribusinya terhadap pembangunan dan pertumbuhan ekonomi. ${ }^{13}$

\section{Metode Penelitian}

Jenis Penelitian ini menggunakan penelitian kualitatif,kuantitatif, deskriptif, library research, yang bertujuan untuk mendeskripsikan suatu keadaan atau fenomena fenomena apa adanya dengan mengambil sumber data dari berbagai dokumen yang mendukung penelitian ini dengan studi dokumentasi.

\section{Hasil dan Pembahasan}

\section{Penyelesaian Pembiayaan Murābaḥah Bermasalah Di Bprs Dana Amanah Surakarta Dilihat Dari Fatwa Dsn Mui}

\section{Penagihan}

Telah dijelaskan pada bab sebelumnya langkah awal jika terjadi pembiayaan murābahah bermasalah di BPRS Dana Amanah Surakarta yakni dengan menghubungi nasabah yang bersangkutan untuk pemberitahuan bahwasanya tanggal pengangsuran telah jatuh tempo. Apabila tanggal jatuh tempo jatuh pada tidak hari kerja BPRS Dana Amanah Surakarta maka nasabah wajib membayar pada saat hari kerja pertama setelahnya.

\footnotetext{
${ }^{11}$ Mulya E Siregar dan Ahmad Buchori, Standar Produk Perbankan Syariah Murābaḥah, Jakarta: Divisi Pengembangan Produk dan Edukasi Departemen Perbankan Syariah Otoritas Jasa Keuangan, 2019, hlm. 19.

${ }^{12}$ Faturrahman Djamil, Penyelesaian Pembiayaan Bermasalah..., hlm. 64.

${ }^{13}$ Ibid.
} 
Dan apabila nasabah masih belum membayar kewajiban angsurannya maka dikenakan penalti ('iwaḍ/kafarāh) sebesar 0,0005 x jumlah angsuran tertunggak perhari yang akan disetorkan rekening ZIS sebagai dana infaq dan shodaqah. Penalti sendiri juga telah tertulis di dalam akad pembiayaan murābaḥah BPRS Dana Amanah Surakarta dan diperuntukan bagi nasabah mampu yang menunda-nunda pembayaran. Sanksi hanya diperuntukkan bagi nasabah yang mampu tetapi menunda pembayaran.

Pada implementasinya BPRS Dana Amanah Surakarta terhadap penalti ('iwaḍ/kafarāh) hanya dikenakan pada nasabah yang memiliki kemampuan membayar tetapi tidak punya itikad baik untuk segera membayar utangnya, jadi penalti diberikan sebagai sanksi agar nasabah tertib dalam menjalankan kewajibannya, untuk penggolongan nasabah yang keadaan force majeur di BPRS Dana Amanah belum terdapat penggolongan secara spesifik, namum apabila dirasa nasabah benar-benar mengalami kesulitan karena usahanya yang jatuh disebabkan musibah maka penalti tidak dijatuhkan. Untuk sejauh ini di BPRS Dana Amanah Surakarta sendiri belum ada menerpakan denda penalti bagi nasabah, baik bagi nasabah yang mampu maupun yang tidak, melainkan selalu mengingatkan nasabah atau penagihan secara langsung kepada nasabah.

Berdasarkan analisis di atas maka klausul pengenaan penalti bagi nasabah yang mampu dan menunda pembayaran pada akad pembiayaan murābaḥah di BPRS Dana Amanah Surakarta telah sesuai dengan Fatwa DSN MUI No. 17/DSN-MUI/IX/2000 tentang Sanksi atas Nasabah Mampu yang Menunda-Nunda pembayaran. Di mana pihak BPRS Dana Amanah Surakarta hanya mengenakan sanksi kepada nasabah mampu yang menunda-nunda pembayaran dan sanksi tersebut juga sudah di sepakati pada awal akad dan tercantum pada akad perjanjian. Walau pada kenyataan implementasinya pengenaan sanksi tidak diterapkan hanya untuk unsur kehati-hatian agar nasabah tertib angsuran.

Mengenai pemberian surat peringatan (SP) tagihan jatuh tempo di BPRS Dana Amanah Surakarta, apabila setelah dihubungi masih terjadi keterlambatan sampai 30 (tigapuluh) hari lebih, maka langkah selanjutnya yang diambil BPRS Dana Amanah Surakarta yakni penagihan dan pemberian surat pemberitahuan serta memberikan SP yakni SP1, teruntuk SP2 dan SP3 diberikan secara kondisional, penagihan sendiri dilakukan dengan cara:

a. Telat membayar selama 30 hari yang menagih tim AO;

b. Telat membayar selama 90 hari yang menagih tim Collection;

c. Telat membayar di atas 91 hari yang menagih tim Remedial.

Untuk ketentuan SP atau somasi tidak ada ketentuan berapa kali somasi harus diajukan, maka dalam praktik, somasi itu umumnya diajukan tiga kali yaitu: SP 1, SP 2, SP 3 bisa juga SP 1 dan SP 3 (Terakhir). SP 1 umumnya berupa peringatan yang masih bersifat soft, karena pihak BPRS Dana Amanah Surakarta biasanya masih meyakini bahwa dengan peringatan tersebut nasabah akan dengan sukarela melaksanakan kewajibannya. 
Sedangkan isi dari SP 2 lebih memberikan peringatan yang lebih tegas dari sebelumnya, apabila masih tidak ada respon dan tanggapan barulah pihak BPRS Dana Amanah Surakarta mengeluarkan SP3 untuk keadaan siap lelang atau membawa ke ranah Peradilan. Dan teruntuk pemberian SP menurut peneliti sudah sesuai Pasal 1238 KUHPer apabila nasabah melakukan wanprestasi maka langkah pertama yang dilakukan dengan memberikan teguran atau peringatan secara tertulis.

\section{Rescheduling}

BPRS Dana Amanah Surakarta memperpanjang jangka waktu pengangsuran dengan sistem perubahan syarat pembiayaan yang menyangkut jadwal angsuran. rescheduling merupakan salah satu bentuk penyelesaian secara musyawarah mufakat dari BPRS Dana Amanah Surakarta terhadap penanganan pembiayaan murābaḥah bermasalah oleh nasabahnya pelaksanaanya dari tahun 2017 kurang lebih sudah 30 (tiga puluh) kali. Tahapan ini merupakan tahapan lanjutan terhadap pemberian surat pemberitahuan tunggakan atau SP 1 apabila nasabah merespon baik dari teguran tersebut. Rescheduling dilakukan apabila nasabah mengajukan permohonan perpanjangan jangka waktu pengangsuran kepada BPRS Dana Amanah Surakarta, tahapan ini diperuntukan bagi nasabah tertentu yang dirasa mampu untuk membayar dengan perpanjangan waktu, memiliki karakter amanah atau nasabah yang sudah dikenal baik oleh BPRS Dana Amanah Surakarta dan masih dirasa kooperatif.

Teruntuk kriteria nasabah yang dapat melakukan rescheduling di BPRS Dana Amanah Surakarta yakni :

a. Nasabah dirasa masih kooperatif;

b. Nasabah masih ada kemauan untuk membayar;

c. Usaha nasabah masih berjalan dan termasuk dalam golongan lancar.

Disini menurut peneliti penetapan kriteria nasabah yang dapat mengajukan rescheduling telah sesuai dengan Pasal 31 POJK No. 29/POJK.03/2019 di mana BPRS dapat melakukan rescheduling pembiayaan terhadap nasabah yang memenuhi kriteria :

a. Mengalami kesulitan pembayaran pembiayaan pokok dan margin;

b. Memiliki prospek usaha yang baik dan dinilai mampu memenuhi kewajiban setelah pembiayaan di restrukturisasi. ${ }^{14}$

Dalam hal pelaksanaan rescheduling di BPRS Dana Amanah Surakarta, sisa angsuran total yang dibayar nasabah jumlahnya tetap tanpa ada tambahan margin namun nasabah masih berkewajiban untuk membayar asuransi karena jangka waktu penutupan proteksi asuransi ditetapkan sesuai dengan jangka waktu pembiayaan.

14 POJK No. 29/POJK. 03/2019 tentang Kualitas Aset Produktif dan Pembentukan Penyisihan Penghapusan Aset Produktif Bank Pembiayaan Rakyat Syariah. 
Semisal mengenai jangka waktu yang sebelumnya di dalam akad jangka waktunya 1 (satu) tahun, dengan total pembiayaan Rp. 10,000,000,- ditambah margin sebesar Rp. 2,000,000,-si nasabah telah membayar pengangsuran selama 6 (enam) bulan dengan angsuran sebesar Rp. 1,000,000/bulan pada bulan ke 7 (tujuh) nasabah mengalami keterlambatan pengangsuran karena tidak sanggup membayar angsuran maka mengajukan permohonan perpanjangan jangka waktu 6 bulan lagi. Maka si nasabah pengangsurannya diubah menjadi Rp. 500,000/bulan dengan jangka waktu 12 (dua belas) bulan lagi. ${ }^{15}$

Berdasarkan dari ketentuan di atas apa yang telah dilakukan oleh BPRS Dana Amanah Surakarta telah sesuai dengan Fatwa DSN MUI No. 48/DSN-MUI/II/2005. Dibuktikan BPRS Dana Amanah Surakarta tidak memberikan tambahan biaya margin terhadap jumlah tagihan yang tersisa kepada nasabah jumlah tagihan tersisa yang harus dibayarkan oleh nasabah tetap sama.

\section{Restructuring}

Pada tahapan ini BPRS Dana Amanah Surakarta melakukan pembaharuan akad, atau bisa disebut dengan konversi akad dengan membuat akad baru bagi nasabah yang tidak bisa menyelesaikan atau melunasi pembiayaan murābaḥahnya. Tahapan ini juga merupakan salah satu bentuk penyelesaian secara musyawarah mufakat dari BPRS Dana Amanah Surakarta terhadap penanganan pembiayaan murābaḥah bermasalah oleh nasabahnya pelaksanaanya dari tahun 2017 kurang lebih sudah 5 (lima) kali. Teruntuk kriteria nasabah yang bisa di restructur di BPRS Dana Amanah Surakarta sama seperti kriteria nasabah reschedule.

Kebijakan untuk mengkonversi akad tidak semata-mata kebijakan yang dipilih sepihak oleh BPRS Dana Amanah Surakarta, melainkan telah dimusyawarahkan dengan pihak nasabah terkait, dan sebelum dilakukannya tahapan restructuring ini haruslah dipertimbangkan opsi-opsi yang lain, misalnya opsi rescheduling dan apabila tidak bisa diselesaikan dengan cara reschedule barulah pihak BPRS Dana Amanah Surakarta menawarkan tahapan ini kepada nasabah dan apabila setuju nasabah mengajukan permohonan untuk restructure.

Dalam pelaksanaannya nasabah menjual objek jaminan kepada BPRS Dana Amanah Surakarta, dan BPRS Dana Amanah Surakarta membeli seharga sisa utang selanjutnya nasabah sepakat melakukan akad baru bisa berupa ijärah muntahiyah bittamlīk (IMBT), mudhārabah dan musyārakah. Akad baru yang digunakan kondisional tergantung permasalahan pembiayaan murābaḥah si nasabah. Objek murābaḥah atau

${ }^{15}$ Purwo Agung Ratmanto, Collection BPRS Dana Amanah Surakarta, Wawancara Pribadi, tanggal 7 Juni 2020, jam 09.00-13.00 WIB. 
jaminan yang sudah menjadi milik BPRS dapat kembali dimiliki oleh nasabah dengan cara akad baru :

a. Akad IMBT, objek murābaḥah/jaminan disewakan oleh BPRS Dana Amanah Surakarta ke nasabah dengan opsi perpindahan kepemilikan kepada nasabah secara hibah.

b. Akad mudhārabah, Objek murābaḥah / jaminan dijadikan modal usaha bersama dengan nasabah dalam jangka waktu tertentu. Nasabah sebagai pengelola (mudhārib). Nasabah membayar pokok dan bagi hasil setiap bulan. Diakhir masa akad objek murābaḥah /jaminan akan menjadi milik nasabah.

c. Akad musyārakah, Objek murābahah/jaminan dijadikan modal usaha bersama dengan nasabah dalam jangka waktu tertentu. Nasabah juga berkontribusi modal dalam bentuk kas atau non-kas. Nasabah sebagai mitra aktif akan mengelola usaha tersebut dan membayar pokok modal dan bagi hasil setiap bulan. Diakhir masa akad objek murābaḥah/jaminan akan menjadi milik nasabah.

Berdasarkan dari ketentuan di atas dapat dilihat bahwasanya penyelesaian pembiayaan murābaḥah dengan cara restructuring di BPRS Dana Amanah Surakarta juga telah sesuai dengan Fatwa DSN MUI No. 49/DSN-MUI/II/2005 teruntuk poin a bagian pertama mengenai penjualan sesuai dengan harga pasar, pada realisasinya penjualan dilakukan di bawah harga pasar (ketetapan harga minimum) atau sejumlah sisa utang, namun pada harga yang telah disepakati oleh kedua belah pihak baik dari nasabah maupun BPRS. Untuk selebihnya telah sesuai hal ini dilihat dari nasabah eks-murābahah yang akadnya dikonversi pada akad IMBT, mudḥārabah dan musyārakah.

\section{Nasabah Menjual Barang Sendiri}

Tahapan ini juga merupakan penyelesaian pembiayaan murābaḥah bermasalah secara musyawarah mufakat yang diberikan BPRS Dana Amanah Surakarta kepada nasabahnya yang mengalami pembiayaan bermasalah. Di sini sebelum diadakannya eksekusi jaminan pihak BPRS Dana Amanah Surakarta memberikan kesempatan terlebih dahulu kepada nasabahnya untuk menjual barang jaminan teruntuk harga penjualan seluruhnya diserahkan kepada nasabah asalkan nantinya bisa menutup sisa utang kewajiban nasabah.

Selain barang yang dijaminkan nasabah juga bisa menjual objek murābaḥah atau harta lain yang dimiliki nasabah asalkan harta tersebut bisa menutupi sisa utang kewajiban nasabah. Untuk jangka waktu penjualan ini bisanya BPRS Dana Amanah Surakarta memberikan waktu maksimal 3 (tiga) bulan, apabila dari hasil penjualan pribadi nasabah masih belum cukup untuk melunasi sisa kewajibannya maka sisa utang masih dianggap kewajiban nasabah, dan apabila hasil penjualan melebihi dari sisa utang maka sisa penjualan sepenuhnya menjadi milik nasabah. Dan jika tidak terjual pada 
jangka waktu yang telah ditentukan maka akan dilaksanakannya eksekusi jaminan oleh pihak BPRS Dana Amanah Surakarta terhadap objek jaminan pembiayaan murābaḥah.

Berdasarkan dari ketentuan di atas maka telah sesuai dengan Fatwa DSN MUI No. 47/DSN-MUI/II/2005 dari poin 1 sampai dengan 4 di mana objek murābahah/jaminan dijual dengan harga yang telah disepakati, nasabah menjual sisa utang dari hasil penjualan, kelebihan dari penjualan sepenuhnya menjadi milik nasabah, apabila dari hasil penjualan lebih kecil maka sisa utang tetap menjadi kewajiban nasabah.

Namun untuk poin 5 yang menjelaskan, apabila nasabah tidak mampu membayar sisa utangnya maka LKS dapat membebaskannya. Menurut peneliti di sini pelaksanaanya belum sesuai. Pada implementasinya di BPRS Dana Amanah Surakarta selama ini belum pernah menerapkan pembebasan tagihan terhadap nasabahnya, melainkan memilih langkah penyelamatan lain dengan cara musyawarah muafakat seperti tahapan restrukturisasi ataupun dengan eksekusi jaminan ditambah penagihan secara intensif, jika dari hasil penjualan eksekusi masih belum bisa melunasi sisa kewajiban apabila dirasa tidak bisa lagi diselesaikan secara musyawarah ketimbang pembebasan utang. Karena bagi BPRS Dana Amanah Surakarta utang nasabah tetaplah utang dan sebagai nasabah juga wajib memenuhi kewajibannya. Hal maksimal yang bisa dilakukan BPRS Dana Amanah hanya sampai pada tahapan hapus buku bukan hapus tagih.

Jadi, disaat ekonomi nasabah membaik dikemudian hari BPRS Dana Amanah Surakarta tetap melakukan penagihan terhadap utang nasabah. Atau cara akhir yang ditempuh jika terjadi pembiayaan murābaḥah bermasalah dengan diselesaikan secara litigasi di Pengadilan Agama. BPRS Dana Amanah Surakarta baru mengangap utang nasabah lunas jika nasabah meninggal dunia, ahli waris sudah tidak ada.

\section{Eksekusi Jaminan}

Pelaksanaan eksekusi hak tanggungan dan fidusia di BPRS Dana Amanah Surakarta dilakukan apabila nasabah sudah masuk pada kolektibilitas 5 atau golongan macet dan jika nasabah sudah dirasa tidak bisa lagi diselesaikan penanganannya dengan beberapa cara di atas atau dipandang sudah tidak dalam kooperatif lagi, seperti tidak ada respon sama sekali dari nasabah dari pemberitahuan tunggakan jatuh tempo sampai dengan pemberian SP3.

BPRS Dana Amanah Surakarta untuk mengeksekusi jaminan hak tanggungan melalui KPKNL dengan menggunakan SKMHT atau surat kuasa menjual tanpa campur tangan pengadilan atau eksekusi dilakukan tanpa perintah eksekusi dari pengadilan. Untuk pelaksanaan eksekusi dilakukan tanpa meminta persetujuan lagi dari nasabah karena semua telah diatur dan disepakati pada saat penandatangan SKMHT, APHT dan akta jaminan fidusia.

Untuk pelaksanaan eksekusi hak tanggungan di BPRS Dana Amanah menurut peneliti telah sesuai pasal 6 UUHT jo pasal 20 ayat 1 huruf (a) di mana pelaksanaan 
eksekusi hak tanggungan dapat dilakukan oleh pemegang hak tanggungan atas kekuasaan sendiri melalui pelelangan umum. Artinya, bahwa pelaksanaan lelang berdasarkan Pasal 6 UUHT merupakan kewenangan yang diberikan oleh undang-undang kepada pemegang hak tanggungan pertama untuk melakukan penjualan melalui pelelangan umum atas aset yang dijadikan sebagai jaminan apabila nasabah wanprestasi terhadap pembiayaannya.

Untuk eksekusi fidusia pihak BPRS Dana Amanah Surakarta harus membuat permohonan mengajukan eksekusi ke Pangadilan Agama terlebih dahulu dan dapat melakukan eksekusi ketika sudah ada putusan incraht. Apabila si pihak nasabah tidak secara sukarela menyerahkan objek fidusianya kepada BPRS Dana Amanah Surakarta.

Dalam Putusan MK No. 18/PPU-XVII/2019 apabila debitur keberatan menyerahkan secara sukarela objek yang menjadi jaminan fidusia, maka segala mekanisme dan prosedur hukum dalam pelaksanaan eksekusi sertifikat jaminan fidusia harus dilakukan dan berlaku sama dengan pelaksanaan eksekusi putusan pengadilan yang telah berkekuatan hukum tetap. ${ }^{16}$

Dalam hal ini peneliti menyimpulkan untuk pelaksanaan eksekusi jaminan fidusia di BPRS Dana Amanah Surakarta juga sudah sesuai dengan putusan MK No. 18/PPU-XVII/2019. Sebelum dilakukannya eksekusi HT dan Fidusia, surat peringatan dari nasabah harus lengkap mulai dari SP1-SP3 dan memeriksa kembali keabsahan semua dokumen pendukung lelang, karena keabsahan dokumen tersebut merupakan tanggung jawab pemohon lelang. Untuk menjual objek jaminan melalui pelelangan di muka umum penetapan harga dilakukan berdasarkan kesepakatan pemberi jaminan (nasabah) dan penerima jaminan (BPRS Dana Amanah Surakarta). Harga awal yang ditawarkan pada saat pelelangan kondisional bisa di bawah harga pasar maupun di atas harga pasar karena harga dipilih dari harga tertinggi perolehan lelang di mana bisa menguntungkan dan bisa merugikan. untuk biaya lelang semua ditanggung oleh nasabah dan jika dari hasil lelang tersebut terdapat sisa maka akan dikembalikan kepada nasabah dan jika hasil lelang tidak mencukupi untuk melunasi sisa utang maka nasabah tetap terikat membayar lunas sisa utang kepada BPRS Dana Amanah Surakarta.

Menurut peneliti untuk kesesuaian implementasinya terhadap fatwa tersebut juga telah sesuai dari poin 1-4 Fatwa DSN MUI No. 47/DSN-MUI/II/2005. Namun untuk poin 5 yang menjelaskan, apabila nasabah tidak mampu membayar sisa utangnya maka LKS dapat membebaskannya. Menurut peneliti di sini pelaksanaanya belum sesuai. Pada implementasinya di BPRS Dana Amanah Surakarta selama ini belum pernah menerapkan pembebasan tagihan terhadap nasabahnya, melainkan memilih langkah penyelamatan

16 Putusan Mahkamah Konstitusi Nomor. 18/PPU-XVII/2019 perihal Pengujian Undang-Undang Republik Indonesia Nomor 42 Tahun 1999 tentang Jaminan Fidusia terhadap Undang-Undang Dasar Negara Republik Indonesia Tahun 1945. 
lain dengan cara restrukturisasi ataupun dengan eksekusi jaminan ditambah penagihan secara intensif, jika dari hasil penjualan eksekusi masih belum bisa melunasi sisa kewajiban ketimbang pembebasan utang. Karena bagi BPRS Dana Amanah Surakarta utang nasabah tetaplah utang. Hal yang dilakukan BPRS Dana Amanah hanya sampai pada tahapan hapus buku bukan hapus tagih.

Jadi, disaat ekonomi nasabah membaik dikemudian hari BPRS Dana Amanah Surakarta tetap melakukan penagihan terhadap utang nasabah. Atau cara akhir yang ditempuh jika terjadi pembiayaan murābaḥah bermasalah dengan diselesaikan secara litigasi di Pengadilan Agama. BPRS Dana Amanah Surakarta baru mengangap utang nasabah lunas jika nasabah meninggal dunia, ahli waris sudah tidak ada.

\section{Agunan Yang Diambil Alih (AYDA)}

Yakni kuasa jual ke bank, proses penyerahan agunan kepada pemegang jaminan/bank baik melalui lelang dan di luar pelelangan. Implementasinya di BPRS Dana Amanah, pernah melaksanakan tahapan ini pada saat nasabah dirasa benar-benar tidak dapat lagi memenuhi prestasinya atau bisa disebut dalam keadaan nasabah macet namun penyelesaian dengan cara ini baru 1 (satu) kali dilakukan oleh BPRS Dana Amanah Surakarta dan tidak sampai selelesai dikarenakan pihak penjamin lebih memilih menyelesaikan secara litigasi di Pengadilan Agama. Pelaksanaannya tidak jauh berbeda dengan eksekusi jaminan di mana jaminan dijual oleh bank dengan surat kuasa menjual oleh nasabah. Jika dilihat dalam ketentuan Fatwa DSN MUI No. 47/DSN-MUI/II/2005 dari poin 1-4 pelaksanaannya telah sesuai, yakni Pihak BPRS Dana Amanah Surakarta menjual objek murābahah/Jaminan dengan surat kuasa menjual apabila terdapat sisa dari hasil penjualan maka akan dikembalikan oleh BPRS Dana Amanah Surakarta kepada nasabah, dan apabila hasil penjualan tidak dapat menutupi sisa utang maka nasabah tetap berkewajiban untuk melunasi sisa utang tersebut kepada BPRS Dana Amanah Surakarta.

Walaupun pada implementasinya penjualan barang jaminan biasanya lebih sering dilakukan di bawah harga pasar karena terdapat jangka waktu maksimal penjualan/pencairan AYDA yakni selama 1 (satu) tahun dalam ketentuan POJK, namun sebelumnya harga tersebut telah disepakati oleh nasabah dan pihak BPRS Dana Amanah Surakarta dan tertuang diharga minimum penjualan dalam surat kuasa menjual dan sebisa mungkin di sini pihak BPRS mencoba menjual dengan harga yang dapat menutup utang nasabah atau setara sisa utang. Apabila BPRS Dana Amanah Surakarta tidak dapat melakukan pencairan pada jangka waktu yang telah ditentukan maka pada laporan posisi keuangan wajib diperhitungkan sebagai faktor pengurangan modal inti atau penurunan penetapan aset produktif (PAP). Pemberian jangka waktu penjualan kembali oleh POJK dimaksud agar dana dapat segera dimanfaatkan oleh BPRS. Selain itu badan pertanahan nasional (BPN) juga menolak transaksi jual beli yang dikuasakan selama lebih dari 1 (satu) tahun. 
Untuk pelaksanaan AYDA ini juga dijelaskan pada Pasal 40 POJK No. 29/POJK.03.2019 dengan ketentuan : ${ }^{17}$

a. BPRS dapat mengambil agunan untuk mempercepat penyelesaian pembiayaan yang memiliki kualitas macet;

b. Pengambil alihan agunan sebagaimana dimaksud bersifat sementara;

c. Pengambil alihan agunan sebagaimana dimaksud harus disertakan dengan surat pernyataan penyerahan agunan atau surat kuasa menjual dari nasabah.

\section{Penyelesaian Melalui Badan Peradilan}

Upaya penyelesaian pembiayaan murābaḥah bermasalah melaui jalur litigasi di BPRS Dana Amanah Surakarta merupakan upaya terakhir untuk melakukan upaya pelancaran kembali pembiayaan nasabah. Dengan cara eksekusi agunan pembiayaan, penagihan pembiayaan kepada penjamin, pengambil alihan agunan pembiayaan oleh BPRS Dana Amanah Surakarta. Penyelesaian melaui jalur litigasi ini ditempuh oleh BPRS Dana Amanah Surakarta bilamana nasabah tidak memiliki itikad baik dan tidak menunjukan kemauan untuk memenuhi kewajibannya sedangkan sebenarnya si nasabah masih mempunyai harta lain yang tidak dikuasai oleh BPRS Dana Amanah Surakarta atau sumber-sumber lain yang sebenarnya dapat melunasi utangnya

BPRS Dana Amanah Surakarta sendiri sangat jarang memilih jalur ini kecuali dalam hal-hal tertentu yang dirasa sangat merugikan pihak bank atau nasabah yang meminta sendiri untuk menyelesaikan melalui jalur peradilan. Pihak BPRS Dana Amanah Surakarta lebih memilih menyelesaikan dengan jalur kekeluargaan atau musyawarah mufakat dengan nasabah karena pada dasarnya jalur litigasi ini membutuhkan dana yang cukup besar dan waktu yang cukup lama, sedangkan apabila si nasabah menjaminkan berupa kendaraan bermotor maka nilainya semakin lama akan semakin menurun.

Pada akad pembiayaan murābaḥah BPRS Dana Amanah Surakarta tertulis untuk penyelesaian perselisihan, apabila musyawarah untuk mufakat telah diupayakan namun tidak dapat diselesaikan oleh kedua belah pihak, maka para pihak bersepakat untuk menyelesaikannya melalui Pengadilan Agama menurut prosedur beracara yang berlaku dalam badan arbitrase tersebut.Dalam Fatwa DSN MUI No. 47/DSN-MUI/II/2005 pada ketentuan penutup dijelaskan jika ada salah satu pihak tidak menunaikan kewajibannya atau terjadi perselisihan di antara pihak-pihak terkait, maka penyelesainnya dilakukan melalui badan arbitrase syariah nasional setelah tidak tercapai kesepakatan musyawarah.

Menurut peneliti penyelesaian pembiayaan murābaḥah pada tahapan akhir yang ditempuh BPRS Dana Amanah Surakarta di sini telah sesuai sebagaimana berdasarkan ketentuan Pasal 55 ayat (1) UU No. 21 Tahun 2008 tentang Perbankam Syariah, yaitu

${ }^{17}$ POJK No. 29/POJK. 03/2019 tentang Kualitas Aset Produktif... 
dalam lingkungan Peradilan Agama, ${ }^{18}$ meskipun demikian tetap diberi kesempatan untuk menyelesaikan dengan cara lain sepanjang ditentukan dalam akad yang diperjanjikan seperti musyawarah, mediasi perbankan, melaui badan arbitrase tetapi dengan ketentuan tidak boleh bertentangan dengan prinsip syariah. ${ }^{19}$

\section{Kesimpulan}

Strategi penyelesaian pembiayaan murābaḥah bermasalah di BPRS Dana Amanah Surakarta di antaranya adalah menghubungi nasabah, penagihan, pemberian SP1-SP3, rescheduling, restructuring, nasabah menjual barang sendiri, eksekusi jaminan, AYDA, dan melaui Pengadilan Agama apabila tidak dapat diselesaikan secara musyawarah mufakat.

Strategi penyelesaian pembiayaan murābaḥah bermasalah di BPRS Dana Amanah Surakarta yang dilakukan menurut peneliti telah sesuai dengan Fatwa DSN MUI No. 17/DSN-MUI/IX/2000 tentang nasabah yang mampu yang menunda-nunda pembayaran, Fatwa DSN MUI No. 48/DSN-MUI/II/2005 tentang penjadwalan kembali tagihan Murābahah, Fatwa DSN MUI No. 49/DSN-MUI/II/2005 tentang Konversi Akad Murābahah dan POJK No. 29/POJK.03.2019 tentang Kualitas Aset Produktif dan Penyisihan Penghapusan Aset Produktif Bagi Bank Pembiayaan Rakyat Syariah. Kecuali dalam Fatwa DSN MUI No. 47/DSN-MUI/II/2005 pada ketentuan poin ke 5 mengenai pembebasan pada nasabah yang benar-benar tidak mampu lagi melunasi pembayaran pembiayaannya. Karena pada implementasinya tahapan terakhir dalam penyelesaian pembiayaan murābaḥah bermasalah di BPRS Dana Amanah Surakarta adalah diseleseikan di Pengadilan Agama, dan untuk pembebasan pembiayaan hanya dilakukan hapus buku bukan hapus tagih di mana walau utang nasabah telah dihapus bukukan tetapi masih terdapat penagihan.

\section{Al-Qur'an}

Kementrian Agama RI, Al-Wasim Al-Qur'an Tajwid Kode Transliterasi Perkata Terjemahan Perkata, Bekasi: Cipta Bagus Segara, 2013.

\section{Buku}

Adjie, Habbib, Merelasikan Pembebanan Hak Tanggungan dengan Eksekusi Hak Tanggungan, Semarang: Duta Nusindo Semarang, 2018. Afifuddin dan Beni Ahmad Saebani, Metodelogi Penelitian Kualitatif. Bandung: Pustaka Setia, 2012.

18 Undang-Undang Nomor 21 Tahun 2008 tentang Perbankan Syariah (Lembar Negara Republik Indonesia Tahun 2008 Nomor 94, Tambahan Lembaran Negara Republik Indonesia Nomor 4867).

19 Habbib Adjie, Merelasikan Pembebanan Hak Tanggungan dengan Eksekusi Hak Tanggungan (Semarang: Duta Nusindo Semarang, 2018), hlm. 41. 
Antonio, Muhammad Syafi'I, Islamic Banking Bank Syariah Dari Teori ke Praktik, cet ke-1, Jakarta: Gema Insani, 2001.

Asro, Muhammad dan Muhammad Kholid, Fiqih Perbankan, Bandung: CV.Pustaka Setia, 2011.

Dewi, Gemala, Aspek-Aspeh Hukum dalam Perbankan dan Perasuransian Syariah di Indonesia,Jakarta: Kencana, 2007.

Dewi, Gemala, dkk., Hukum Perkatan Islam di Indonesia, Jakarta: Kencana, 2005.

Djamil, Faturrahman, Penyelesaian Pembiayaan Bermasalah di Bank Syariah, Jakarta: Sinar Grafika, 2014.

Janwari, Yadi. Lembaga Keuangan Syariah, Bandung: PT Remaja Rosdakarya.

Lexy J, Moleong, Metodelogi Penelitian Kualitatif, Bandung: Rosda, 2009.

Mardani, Fiqh Ekonomi Syariah (Fiqh Muamalah), Cet.4, Jakarta: Kencana. 2016.

Meliala, S Djaja, Abu Achmadi, Perkembangan Hukum Perdata tentang Benda dan Hukum Perikatan, Bandung: Nuansa Aulia, 2008.

Milles B, Mattew, A.M. Huberman, Analisis Data Kualitatif, Jakarta:Universitas Indonesia, 2007.

Muljadi, Etika dan Komunikasi Bisnis Islam, Jakarta: Salmeba Diniyah, 2019.

Mustofa, Imam, Fiqih Mu'amalah Kontemporer, cet ke-1, Jakarta: Rajawali Pers, 2016.

Narbuko, Cholid, Abu Achmadi, Metodologi Penelitian, Jakarta: PT Bumi Aksara, 2004.

Nasution, Metode Research, Jakarta: Bumi Aksara, 2016.

Sam, Ichwan, dkk, (ed), Himpunan Fatwa Keuangan Syariah Dewan Syariah Nasional MUI, Jakarta: Erlangga, 2014.

Sarwono, Jonathan, Metode Penelitian Kuantitatif dan Kualitatif, Yogyakarta: Graha Ilmu, 2006.

Simanjuntak, Bungaran Antonious, Metode Penelitian Sosial, Jakarta: Yayasan Pustaka Obor Indonesia, 2014.

Siregar, Mulya E dan Ahmad Buchori, Standar Produk Perbankan Syariah Murābaḥah, (Jakarta: Divisi Pengembangan Produk dan Edukasi Departemen Perbankan Syariah Otoritas Jasa Keuangan, 2019).

Sudarsono, Heri, Bank dan Lembaga Keuangan Syariah Deskripsi dan Ilustrasi, Yogyakarta: Ekonisia, 2008.

Sugiyono, Metodelogi Penelitian Kuantitatif, Kualitatif, dan R\&D. Bandung: Alfabeta, 2018.

Sujarweni, Wiratama, Metode Penelitian, Yogyakarta: PT.Pustaka Baru, 2014.

Suwiknyo, Dwi. Kamus Lengkap Ekonomi Islam, cet ke-1, Yogyakarta: Total Media, 2009.

Tarmizi, Erwandi, Harta Haram Kontemporer, cet ke-4, Bogor: PT.Berkat Mulia Insani, 2013.

Umam, Khotibul. Legislasi Fikih Ekonomi dan Peneraoannya dalam Produk Perbankan, cet ke-1, Yogyakarta: BPFE). 2011. 
Umam, Khotibul. Perbankan Syariah Dasar-Dasar dan Dinamika Perkembangannya di Indonesia, Jakarta: PT Raja Grafindo Persada, 2016.

\section{Internet}

Otoritas Jasa Keuangan, "Laporan Keuangan Perbankan", dikutip dari https://www.ojk.go.id/id/kanal/perbankan/data-dan-statistik/laporankeuangan-perbankan/default.aspxdiunduh 25 Juni 2020, jam 10:58 WIB.

BPRS Dana Amanah Surakarta, "Profil BPRS Dana Amanah Surakarta. https://bprsdanaamanah.com/ diaskes 3 Februari 2020, jam 12.00 WIB.

\section{Jurnal}

Azizah, Nur. "Tinjauan Hukum Islam terhadap Penyelesaian Pembiayaan Mudharabah pada Nasabah yang Pailit di PT BNI Syari'ah Cabang Ngagel Surabaya”, Jurnal Maliyah, Vol.05 Nomor 01, 2015.

Ibrahim, Azharsyah dan Arinal Rahmawati, "Analisis Solutif Penyelesaian Pembiayaan Bermasalah di Bank Syariah Kajian Pada Produk Murabahah di Bank Muamalat Indonesia, "Jurnal Kajian Ekonomi Islam dan Hukum, (Banda Aceh) Vol. 7 Nomor 2, 2017.

Isnaini, Rindang Nuri dan Syafrildha Bimo,"Analisis Faktor Internal Bank dan Eksternal terhadap Non-Performing Financing pada Bank Pembiayaan Rakyat Syariah di Indonesia, "Jurnal Ekonomi dan Keuangan Islam, (Yogyakarta) Vol. 5 Nomor 1.

Maidalena,"Analisis Faktor Non Performing Financing (NPF) Pada Industri Perbankan Syariah," Jurnal Human Falah, (Sumatra Utara) Vol. 1 Nomor 1, 2014.

Ubaidillah, "Analisis Faktor-Faktor yang Mempengaruhi Profitabilitas Bank Syariah di Indonesia," Jurnal El-Jizya, (Purwokerto) Vol. 4 Nomor 1, 2016.

Yulianti, Timorita Rahmani, "Asas-asas perjanjian akad dalam hukum kontrak syariah", Jurnal la-Riba Ekonomi Islam, (Yogyakarta) Vol. 2 Nomor 1, 2008.

\section{Kitab Hadist Terjemahan}

Abu Abdullah Muhammad bin Idris Asy-Syafi'I, Musnad Imam Syafi'i, "Kitab Musnad Imam Syafi'i",Terj. Rahmatullah, dkk, II: 569-570, Jakarta: Pustaka Azzam, 2008.

Al Albani, Muhammad Nashirudin, Shahih Sunan Abu Daud Seleksi Hadist Shahih dari Kitab Sunan Abu Daud, "Kitab Sunan Abu Daud", Terj. Abd Mufid Ihsan, dkk, II: 601, Jakarta : Pustaka Azzam, 2006.

Imam Malik bin Anas, Al Muwaththa' Imam Malik, "Kitab al Muwaththa'lil Imam Malik", Terj. Muhammad Iqbal Qadir, II: 97, Jakarta : Pustaka Azzam, 2013.

\section{Peraturan Perundang-Undangan}

Undang-Undang Nomor 21 Tahun 2008 tentang Perbankan Syariah (Lembar Negara Republik Indonesia Tahun 2008 Nomor 94, Tambahan Lembaran Negara Republik Indonesia Nomor 4867).

\section{Peraturan-Peraturan}


Salinan Peraturan Otoritas Jasa Keuangan Republik Indonesia No. 29/P0JK.03/2019 tentang Kualitas Aset Produktif dan Pembentukan Penyisihan Penghapusan Aset Produktif Bank Pembiayaan Rakyat Syariah (lembar Negara Republik Indonesia Tahun 2019 Nomor 228, Tambahan Lembaran 6424).

Fatwa DSN MUI No. 17/DSN-MUI/IX/2000 tentang Sanksi atas Nasabah yang Mampu yang Menunda Pembayaran.

Fatwa DSN MUI No. 47/DSN-MUI/II/2005 tentang Penyelesaian Piutang Murābaḥah Bagi Nasabah yang Tidak Mampu Membayar.

Fatwa DSN MUI No. 48/DSN-MUI/II/2005 tentang Penjadwalan Kembali Tagihan Murabahah.

Fatwa DSN MUI No. 49/DSN-MUI/II/2005 tentang Konversi Akad Murabahah.

\section{Putusan Pengadilan}

Putusan Mahkamah Konstitusi Nomor. 18/PPU-XVII/2019 perihal Pengujian UndangUndang Republik Indonesia Nomor 42 Tahun 1999 tentang Jaminan Fidusia terhadap Undang-Undang Dasar Negara Republik Indonesia Tahun 1945.

\section{Skripsi}

Amidah, Andri Nur,"Implementasi Perlindungan Hukum Bagi Bank TTerhadap Pembiayaan Musyarakah Bermasalah Dengan Jaminan Hak Tanggungan (Studi Kasus di Bank Pembiayaan Rakyat Syariah Dana Mulia Surakarta)", Skripsi, tidak diterbitkan, Program Studi Hukum Ekonomi Syariah, Fakultas Syariah, Institut Agama Islam Negeri Surakarta, Surakarta , 2018.

Setiawan, Yoga, "Analisis Peran Remedial Dalam Mengatasi Pembiayaan Bermasalah Serta Cara Penyelesaiannya Pada PT. BPRS Sukowati Sragen Kantor Cabang Boyolali", Skripsi, tidak diterbitkan, Program Studi Perbankan Syariah, Fakultas Ekonomi dan Bisnis Islam, Surakarta , 2017.

\section{Tesis}

Udhiyati, Noor Hafizah, "Penyelesaian Pembiayaan Murābahah Bermasalah (Studi Kasus di Pengadilan Agama Kota Banjarmasin)”, Tesis, tidak diterbitkan, Pasca Sarjana Magister Ekonomi Syariah, Universitas Islam Negeri Maulana Malik Ibrahim, Malang, 2017.

\section{Wawancara}

Heri Dwi Utomo, Kuasa Hukum Nasabah, Wawancara Pribadi, tanggal 3 Juni 2020, jam 10.00-13.00 WIB.

Ida Nihayah, SE.,Ak, Direksi BPRS Dana Amanah Surakarta, Wawancara Pribadi, tanggal 19 Juni 2020, jam 09.00-13.00 WIB.

Ida Nihayah, SE.,Ak, Direksi BPRS Dana Amanah Surakarta, Wawancara Pribadi, tanggal 27 Juli 2020, jam 09.00-13.00 WIB. 
Mohammad Zuhdi, Nasabah, Wawancara Pribadi, tanggal 25 Juli 2020, jam 13.00-14.00 WIB.

Putri, Costummer Service BPRS Dana Amanah Surakarta, Wawancara Pribadi, tanggal 5 Maret 2020, jam 09.00-13.00 WIB.

Purwo Agung Ratmanto, Collection BPRS Dana Amanah Surakarta, Wawancara Pribadi, tanggal 9 Maret 2020, jam 09.00-12.00 WIB.

Purwo Agung Ratmanto, Collection BPRS Dana Amanah Surakarta, Wawancara Pribadi, tanggal 13 April 2020, jam 09.00-12.00 WIB.

Purwo Agung Ratmanto, Collection BPRS Dana Amanah Surakarta, Wawancara Pribadi, tanggal 28 Mei 2020, jam 09.00-13.00 WIB.

Purwo Agung Ratmanto, Collection BPRS Dana Amanah Surakarta, Wawancara Pribadi, tanggal 7 Juni 2020, jam 08.30-12.00 WIB.

Purwo Agung Ratmanto, Collection BPRS Dana Amanah Surakarta, Wawancara Pribadi, tanggal 19 Juni 2020, jam 08.30-12.00 WIB.

Purwo Agung Ratmanto, Collection BPRS Dana Amanah Surakarta, Wawancara Pribadi, tanggal 27 Juli 2020, jam 12.33-13.00 WIB.

Sulistyowati, Nasabah, Wawancara Pribadi, tanggal 9 Juni 2020, jam 12.00-13.00 WIB. 